\title{
Mannbjörg á Möðrudal á Fjöllum
}

\author{
Pórir Svavar Sigmundsson ${ }^{1,5}$ í sérnámi, Bjarni Árnason² deildarlæknir, Póra Elísabet Kristjánsdóttir ${ }^{3}$ kandídat, Vilhjálmur Vernharðsson ${ }^{4}$ \\ björgunarsveitarmaður
}

\section{ÁGRIP}

27 ára kona fékk krampakippi og varð skyndilega púlslaus á Möðrudal á Fjöllum, fjarri heilbrigðispjónustu. Eftir klukkustundar endurlífgun preifaðist púls að nýju. Hún var flutt með sjúkraflugi á Landspítala par sem hún var greind með stórt blóðrek í lungum. Hún var kæld i 24 klukkustundir og útskrifaðist af sjúkrahúsi á 14. degi án skerðingar á heilastarfsemi. Jafnvel við erfiðar aðstæður fjarri heilbrigðispjónustu getur lífskeðjan reynst sterk pegar boð um aðstoð berast hratt, endurlífgun hefst án tafar og sérhæfð meðferð er veitt eins fljótt og hægt er.

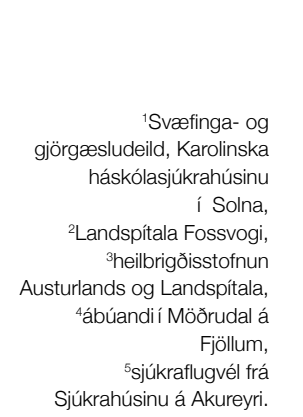

Sjúkrahúsinu á Akureyri. Pórir Svavar Sigmundsson thorir.sigmundsson@ karolinska.se

\section{Sjúkratilfelli}

27 ára gömul erlend kona var á ferðalagi á Möðrudal á Fjöllum. Hún hneig skyndilega niður og fékk endurtekna krampakippi sem stóðu yfir í 1-2 mínútur. Pegar hún komst til meðvitundar gat hún kinkað kolli við spurningum, en ekki tjáð sig á annan hátt. Samferðamenn komu henni til aðstoðar og björgunarsveitarmaður sem býr á staðnum gerði Neyðarlínu viðvart. Kippirnir endurtóku sig í tvígang með 15 mínútna millibili og eftir priðja skiptið stöðvaðist öndun og púls preifaðist ekki. Björgunarsveitarmaður hóf hjartahnoð umsvifalaust og veitti munn við munn öndunarhjálp. Fimm mínútum síðar kom að sjúkralið frá Egilsstöðum og var hún pá greind með rafvirkni án dæluvirkni (Pulseless Electric Activity - PEA) en tók einstaka andköf. Öndunarvegi var haldið opnum með kokrennu og súrefni blásið í lungu með öndunarbelg, æðaleggjum var komið fyrir og adrenalín gefið samkvæmt leiðbeiningum.

Kallað var eftir aðstoð sjúkraflugvélar en við lendingu á Mývatnsflugvelli sprakk á afturhjóli vélarinnar. Sent var strax eftir flugvirkja sem kom með flugvél frá Akureyri til að gera við dekkið. Á Möðrudal var LTS II túbu (Laryngeal Tube Suction) komið fyrir í öndunarvegi og endurlífgun var haldið áfram í sjúkrabíl að Mývatni, en konan var eftir sem áđur púlslaus. Við komu í flugskýli Mýflugs á Mývatni, rúmlega klukkustund eftir að endurlífgun hófst, mátti skyndilega greina sterkan púls í hálsslagæð. Blóðprýstingur mældist 140/76 mmHg og púls 124 slög á mínútu. Hjartarit sýndi sínustakt og engar greinanlegar ST-breytingar. Á meðan á pessu stóð var konan barkaprædd og andaði skömmu síðar sjálf með stuðningi, en purfti $80-90 \%$ súrefnishlutfall og háan innöndunarprýsting til að viðhalda eðlilegri súrefnismettun. Miðbláæðalegg var komið fyrir í vinstri lærisbláæð og vökvi og glúkósi gefinn í æð. Samskonar legg var komið fyrir í slagæð hægra megin til að mæla slagæðarprýsting í rauntíma. Líkamshiti var ekki mældur í flutningi, en henni leyft að kólna með pví að fjarlægja mestan hluta af fatnaði og vökvar sem runnu inn voru við umhverfishita $\left(12-20^{\circ} \mathrm{C}\right)$. Pegar viðgerð á hjólbarða var lokið var flogið með sjúkling áleiðis til
Reykjavíkur. Blóðprýstingur byrjaði að lækka og purfti æðavirk lyf í dreypi til að halda blóðprýstingi stöðugum. Skömmu fyrir lendingu byrjaði hún að hreyfa hægri handlegg og báða fætur.

Við komu á bráđadeild Landspítala sýndi hjartalínurit sínushraðtakt án teikna um blóðpurrð í hjartavöðva. Tölvusneiðmynd af höfði sýndi ekkert óeðlilegt. Hiti við komu á gjörgæsludeild var $34^{\circ} \mathrm{C}$. Hjartaómun sýndi áberandi stækkaðan hægri slegil, príblöðkulokuleka, og önnur teikn lungnaháprýstings. Tölvusneiðmynd og æðamyndataka af lungnablóðrás með skuggaefni staðfesti stórt blóðrek í hægri lungnaslagæð og minna blóðrek á víð og dreif í báđum lungum. Hafin var blóðpynning með enoxaparíni en talið var of áhættusamt að gefa segaleysandi lyf vegna langrar endurlífgunar. Með virkri kælingu var líkamshita haldið við $32-34^{\circ} \mathrm{C}$ í sólarhring og síðan var hún hituð upp $137^{\circ} \mathrm{C}$. Tveimur sólarhringum eftir komu á gjörgæslu var hún vakin og skömmu síðar var öndunarvél aftengd og barkarenna fjarlægð. Við skoðun var hún skýr og áttuð og mundi atburðarás fram að pví að hún hneig niður. Ekki varð vart einkenna eða teikna um skaða á miðtaugakerfi. Hún var flutt á legudeild á 5. degi og útskrifaðist paðan á 14. degi í góðu ástandi. Hún hafði tekið getnaðarvarnartöflur um nokkurra ára skeið. Uppvinnsla á segahneigð var ráðgerð í heimalandi hennar.

\section{Umræður}

Rannsóknir sýna að pví fyrr sem hjartahnoð hefst eftir að sjúklingur hnígur niður, og pví meiri gæði á hjartahnoði, peim mun meira aukast lífslíkur sjúklinga sem fara í hjartastopp. ${ }^{1}$ Nýjar klínískar leiðbeiningar frá árinu 2010 leggja nú áherslu á að hefja hjartahnoð áđur en hugað er að öndunarvegi og að trufla hjartahnoð sem minnst. Hnoða skal 30 sinnum og blása tvisvar. Að tveimur mínútum liðnum skal kanna púls en ekki lengur en í 10 sekúndur. Markmiðið er að halda uppi viðunandi blóðprýstingi til að viðhalda blóðflæði til heila. Ef um stuðvænlegan takt er að ræða, sleglatif 


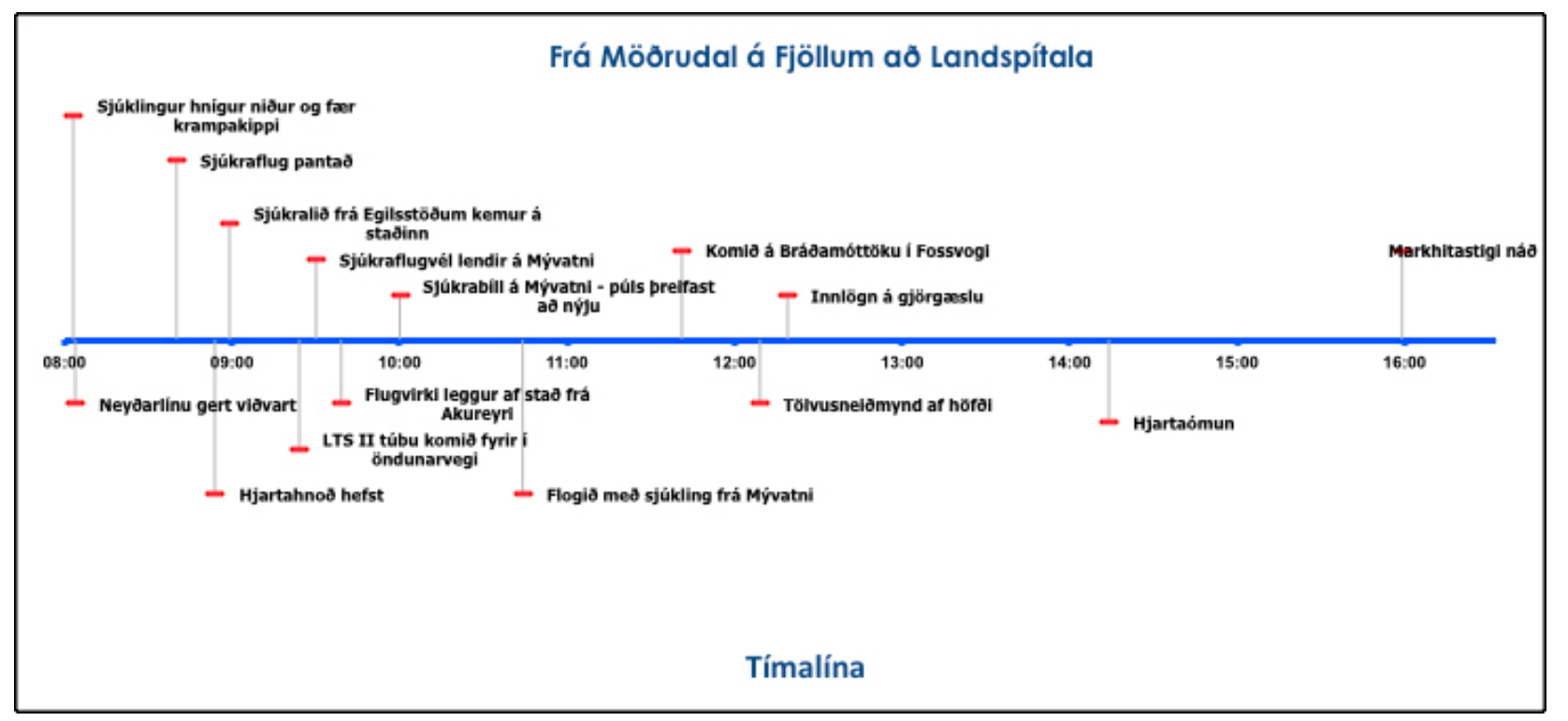

Mynd 1. Lína sem sýnir tímann frá pví sjúklingur veikist á Norðausturhorninu par til hann er kominn á Landspítala og búinn að fara í hjartaómun, pað eru 6 klukkutímar alls.

eða sleglahraðtakt, skal gefa rafstuð hratt og örugglega. ${ }^{2}$ Með góðu hjartahnoði má ná upp slagprýstingi kringum $110 \mathrm{mmHg}$ og meðalprýstingi í kringum $44 \mathrm{mmHg}$, mælt í lærisslagæð. ${ }^{3} \mathrm{Ef}$ innankúpuprýstingur (intracranial pressure - ICP) er eðlilegur ætti gegnumflæðisprýstingur til heila (cerebral perfusion pressure - CPP) að geta verið 30-37 mmHg. Andköf geta verið merki um gegnumflæði til heilastofns og sýna rannsóknir aukna lifun hjá einstaklingum sem taka andköf. Aldrei skal hætta endurlífgun á meðan andköf eru til staðar. ${ }^{4}$

Pegar hjartahnoð er hafið er nauðsynlegt að opna öndunarveg sjúklings og koma súrefni niður í lungu. Í sérhæfðri endurlífgun hefur barkapræðing með aðstoð barkakýlissjár (laryngoscope) lengi verið talin besta aðferðin til að tryggja öndunarveg pannig að magainnihald geti ekki runnið ofan í lungu. Rannsóknir sýna hins vegar að barkapræðing getur beinlínis verið hættuleg ef hún er framkvæmd af heilbrigðisstarfsfólki með ónóga reynslu, par sem barkarenna hafnar í ófáum tilfellum í vélinda og uppgötvast seint. ${ }^{5}$ Til að ná færni í barkapræðingum parf fleiri tugi tilfella við bestu aðstæður á skurðstofu ${ }^{6}$ og eru svæfingalæknar sá hópur sem nær bestum árangri í barkapræðingum utan spítala. ${ }^{7}$ Prátt fyrir pað líta svæfingalæknar sem starfa á sjúkrapyrlum í Noregi á barkapræðingar utan spítala sem mjög áhættusamt inngrip og telja sig purfa enn meiri pjálfun til að takast á við slíkar aðstæður. 75\% peirra höfðu einhvern tíma áður lent í erfiðleikum með að barkapræða utan spítala og rúmur helmingur hafði vitneskju um tilfelli par sem sjúklingur hafði látið lífið vegna pess að ekki var hægt að halda öndunarvegi opnum. ${ }^{8}$ Rannsóknir á LTS II-túbum hafa hins vegar sýnt að læknar og bráðatæknar með litla sem enga reynslu af notkun LTS II purfa langflestir einungis tvær eða færri tilraunir til að koma túbunni á réttan stað og flestir gera pað á innan við 45 sekúndum. ${ }^{9}$ Í okkar tilfelli var lofti blásið niður með munn við munn aðferð og síðan með öndunarbelg par til LT-S-túba var sett niður í annarri tilraun af læknakandídat með enga fyrri reynslu af notkun hennar. Barkapræðing var síðan framkvæmd af lækni í sérnámi í svæfingalækningum til að tryggja öndunarveg frekar fyrir áhættusaman flutning og til að geta veitt sérhæfða öndun- araðstoð með öndunarvél. LTS II er í öllum sjúkrabílum um allt land og ætti ætíð að vera fyrsta val par til frekari hjálp berst.

Byrjað var að kæla sjúkling strax eftir að púls preifaðist við Mývatn með pví að fjarlægja fatnað og gefa vökva sem voru við umhverfishita $\left(12-20^{\circ} \mathrm{C}\right)$. Hitastig við komu á gjörgæsludeild Landspítala var $34^{\circ} \mathrm{C}$. Í samræmi við klínískar leiðbeiningar var líkamshita haldið milli $32-34^{\circ} \mathrm{C}$ í 24 klukkustundir. Sýnt hefur verið fram á ávinning af kælingu í hjartastoppi hjá sjúklingum með sleglatif og sleglahraðtakt og nýlegar rannsóknir benda til að einnig sé ávinningur af kælingu hjá sjúklingum með rafleysu og rafvirkni án dæluvirkni. ${ }^{10}$ Rétt er að byrja að huga að kælingu um leið og púls preifast að nýju en varast skal skjálftaviðbrögð par sem súrefnisupptaka og álag á hjarta aukast umtalsvert. Pví krefst slík meðferð oft djúprar svæfingar og í einstaka tilfellum vöðvaslakandi lyfja.

Að lifa af hjartastopp með rafvirkni án dæluvirkni eftir rúmlega klukkustundar hjartahnoð við erfiðar aðstæður, án pess að heilastarfsemi skerðist verður að teljast merkilegt. Áður er lýst svokölluðu gervipúlsleysi ( $p s e u d o-P E A$ ) par sem viss dæluvirkni er til staðar en pó ekki nægjanleg til að púls preifist í hálsslagæð. Erfitt er að greina á milli PEA og Pseudo-PEA nema með hjartaómun og mælingu koltvísýrings í útöndunarlofti (EtCO2) sem pví miður var ekki mögulegt í pessu tilfelli. Púls í hálsslagæð getur verið erfitt að greina, jafnvel fyrir reynt heilbrigðisstarfsfólk, og ennpá erfiðara í flutningi. ${ }^{11}$ Lífslíkur sjúklinga með PEA eru almennt litlar en með aðstoð ómtækis utan spítala má bæta lífslíkur til muna með snöggri greiningu og sérhæfðri meðferð. ${ }^{12,13}$ Skyndileg endurkoma púls í pessu tilfelli verður ekki skýrð með öðrum hætti en að blóðrek, sennilega söðulrek (saddle pulmonary embolus), hafi færst úr stað eða brotnað upp, mögulega við hjartahnoðið, en pví hefur áður verið lýst eftir hnoð með hnoðtæki (LUCAS $\left.{ }^{\mathrm{TM}} \mathrm{CPR}\right){ }^{14}$

Að veikjast eða slasast alvarlega fjarri byggð eykur hættu á óafturkræfum skaða eða jafnvel dauða. Sjúkraflugvél veitir sérhæfða pjónustu á norðurhluta Íslands og Vestmannaeyjum og er mönnuð svæfingalækni pegar tilefni er til. Heildarflutningstími við bráðatilfelli frá Norður- og Austurlandi utan Akureyrar er að 
A
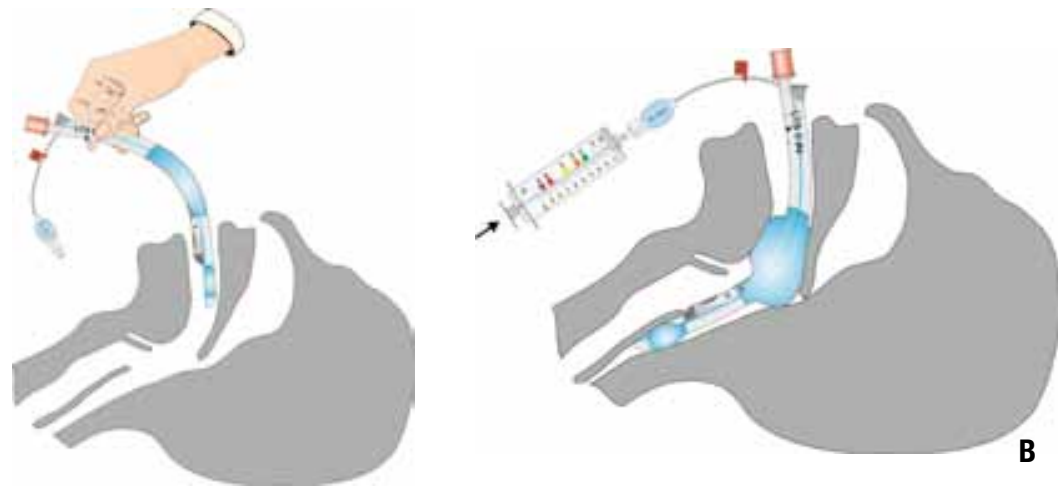

C

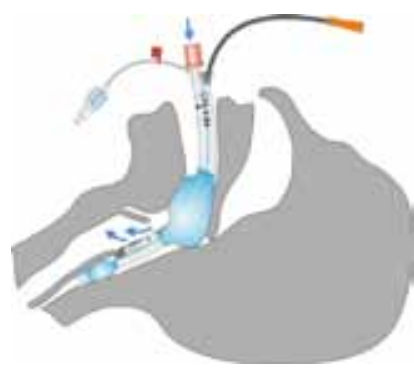

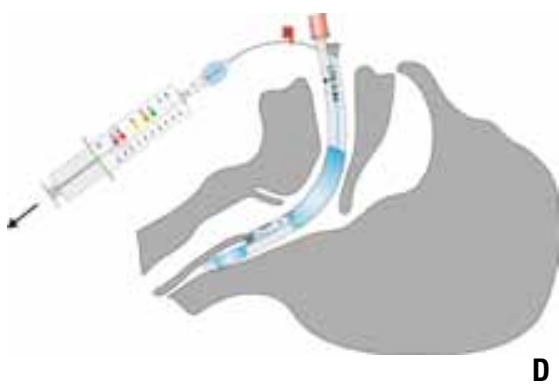

Mynd 2. Ísetning LTS II-túbu.

A) Veljið rétta starð eftir pyngd sjúklings. Smyriið túbuna með geli eða vatni. Haldiða á túbunni eins og penna og opnið munninn á sjúklingnum með lausu hendinni. Setjið túbuna i munninn með flata endann á oddi túbunnar upp að harða gómnum. Rennið túbunni niðður i kok eftir paki munnsins par til svarta strikið̃ á nærenda túbunnar nemur við framtennur í efri gómi. Gxtið pess að tungan dragist ekki með og prústist nið̌ur í kok. B) Sprautið lofti í belginn (cuff) með sprautunni sem fylgir túbunni. Rúmmálið ræđðst af stærð túbunnar (fylgið litakódum á sprautunni). Fyrst blæst nærlægi belgurinn út og pegar hann hefur fyll út í kokið og mótprýstingur skapast, fyllist fjerbelgurinn sem liggur efst ivélindanu.

C) Blásið lofti i túbuna og fylgist með hvort brjóstkassinn lyftist. Hlustið eftir öndunarhlióðum yfir báđum lungum og tengið koltvísýringsmæli i nærenda túbunnar (ef hann er til staðar). Ef öndun er ófullnægjandi má reyna að hnika túbunni niður eða upp. Setjið magasondu niður í dren-gatið á túbunni og sjúgið upp magainnihald eða tengið við drenpoka.

D) Begar fjarlægja á túbuna er loftið dregið úr belgnum og túban dregin út.

Sjá nánar á larynx-tubus.de/larynx-tubus/content/ view/26/122/lang,en/ Birt með leyfi rétthafa. miðgildi prjár klukkustundir og 20 mínútur. ${ }^{15}$ Tafir vegna dekkjaskipta urðu einungis 20 mínútur, pökk sé snörum viðbrögðum flugmanna og flugvirkja. Lífi ungrar konu var bjargað fjarri spít- ala; pökk sé öflugu hjartahnoði sem hófst án tafar, öndunaraðstoð sem var veitt í samræmi við pjálfun björgunaraðila og sérhæfðri meðferð, meðal annars kælingu sem var hafin eins fljótt og hægt var. Pjálfun í endurlífgun bjargar mannslífum.

\section{Heimildir}

1. Sasson C, Rogers MA, Dahl J, Kellermann AL. Predictors of survival from out-of-hospital cardiac arrest: a systematic review and metaanalysis. Circ Cardiovasc Qual Outcomes. 2010; 3: 63-81

2. Hazinski MF, Nolan JP, Billi JE, Böttiger BW, Bossaert $\mathrm{L}$, de Caen AR, et al. Part 1: executive summary: 2010 International Consensus on Cardiopulmonary Resuscitation and Emergency Cardiovascular care with treatment recommendations. Circulation 2010; 122 (16 Suppl 2): S250-75.

3. Hoppu S, Sanio M, Huhtala H, Eilevstjønn J, Tenhunen J, Olkkola KT. Blood pressure during resuscitation in man - The effect of pause during rythm analysis revisited. Resuscitation 2011; 82: 1460-63.

4. Zuercher M, Ewy GA. Gasping during cardiac arrest. Curr Opin Crit Care 2009; 15: 185-8.

5. Timmermann A, Russo SG, Eich C, Roessler M, Braun $\mathrm{U}$, Rosenblatt $\mathrm{WH}$, et al. The out of hospital esophageal and endobronchial intubations performed by emergency physicians. Anesth Analg 2007; 104: 619-23.

6. Konrad C, Schüpfer G, Wietlisbach M, Gerber H. Learning manual skills in anesthesiology: Is there a recommended number of cases for anesthetic procedures? Anesth Analg 1998; 86: 635-9.
7. Breckwoldt J, Klemstein S, Brunne B, Schnitzer L, Arntz HR, Mochmann HC. Expertise in prehospital endotracheal intubation by emergency medicine physicians - Comparing "proficient performers" and "experts" Resuscitation 2012; 83: 434-9.

8. Sollid SJ, Heltne JK, Søreide E, Lossius HM. Pre-hospital advanced airway management by anaesthesiologists: is there still room for improvement? Scand J Trauma Resusc Emerg Med 2008; 21; 16: 2

9. Schalk R, Byhahn C, Fausel F, Egner A, Oberndörfer D, Walcher $\mathrm{F}$ et al. Out of hospital airway management by paramedics and emergency physicians using laryngeal tubes. Resuscitation 2010; 81: 323-6.

10. Walters JH, Morley PT, Nolan JP. The role of hypothermia in post-cardiac arrest patients with return of spontaneous circulation: a systematic review. Resuscitation 2011; 82 :508-16.

11. Lapostolle F, Le Toumelin P, Agostinucci JM, Catineau J, Adnet F. Basic cardiac life support providers checking the carotid pulse: performance, degree of conviction, and influencing factors. Acad Emerg Med 2004; 11: 878-80.
12. Prosen G, Križmari M, Završnik J, Grmec S. Impact of modified treatment in echocardiographically confirmed pseudo-pulseless electrical activity in out-of-hospital cardiac arrest patients with constant end-tidal carbon dioxide pressure during compression pauses. J Int Med Res 2010; 38: 1458-67.

13. Byhahn C, Müller E, Walcher F, Seeger FH, Breitkreutz R. Prehospital Echocardiography in Pulseless Electrical Activity Victims. Anesthesiology 2006; 105: A1735.

14. Bonnemeier $\mathrm{H}$, Simonis $\mathrm{G}$, Olivecrona $\mathrm{G}$, Weidtmann B, Götberg M, Weitz G, et al. Continuous mechanical chest compression during in-hospital cardiopulmonary resuscitation of patients with pulseless electrical activity. Resuscitation 2011; 82: 155-9.

15. Sigmundsson PS, Gunnarsson B, Benediktsson S, Gunnarsson GP, Dúason S, Porgeirsson G. Flutningstími og gæð meðferðar hjá sjúklingum með ST-hækkunar hjartadrep a Norður- og Austurlandi. Læknablaðid 2010; 96: 159-65.

\section{ENGLISH SUMMARY}

\section{Successful resuscitation of a pulseless young woman with pulmonary embolus in rural Iceland}

Sigmundsson TS, Arnason B, Kristjansdottir TE, Vernhardsson V

A 27 year old woman suffered a witnessed cardiac arrest in rural lceland and regained pulse after one hour's resuscitation. She was transported by an air ambulance to a tertiary medical center in Reykjavik where she was diagnosed with a large pulmonary embolus. After 24 hours therapeutic hypothermia she was rewarmed and extubated two days later. She was discharged from the hospital after two weeks neurologically intact. This case illustrates that even in rural circumstances the chain of survival works if all the links are strong, with early access, early resuscitation and early advanced care.

Keywords: cardiac arrest, air ambulance transport, pulmonary embolus, cardiopulmonary resuscitation, pseudo pulseless electrical activity

Correspondence: Pórir Svavar Sigmundsson thorir.sigmundsson@karolinska.se

'Department of Anaesthesia and Critical Care, Karolinska University Hospital, Solna ${ }^{2}$ Department of Anaesthesia and Critical Care, The National University Hospital of Iceland ${ }^{3}$ Intern-

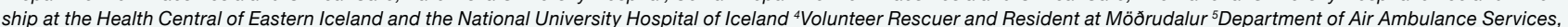
Akureyri Teaching Hospital 